\title{
Zika Virus Infection and Sexual Transmission: A Serious Challenge in the Public Health of the Societies
}

\author{
Sayed Alireza Mirsane, ${ }^{1, *}$ and Nasrin Oraei ${ }^{2}$ \\ ${ }^{1}$ Surgical Technologist, Kashan University of Medical Sciences, Kashan, IR Iran \\ ${ }^{2}$ Lecturer of Education Office, Esfahan, IR Iran \\ "Corresponding author: Sayed Alireza Mirsane, Kashan University of Medical Sciences, Kashan, IR Iran. E-mail: alireza.seyed70@gmail.com
}

Received 2016 November 11; Accepted 2016 November 14.

Keywords: Zika Virus, Infection, Sexual Transmission

\section{Dear Editor,}

Zika virus (ZIKV) is a mosquito-borne flavivirus and its infection is an emergency and a progressive difficulty for public health. It can influence the nervous system and cause serious problems for human embryos (1-4). ZIKV infection in pregnant women causes birth of newborns suffering from microcephaly. In this regard, researchers in a recent study conducted on mice reported that ZIKV causes infection in the fetus by infecting the trophoblastic cells in the placenta, which can occur via transplacenta route. Unfortunately, this problem could be a constraint in intrauterine and apoptosis in brain cells. Results of other studies revealed ZIKV in human fetal brain tissue. Moreover, ultrasonography ascertained the microcephaly with calcifications in 29 weeks of gestation in mothers infected with $\operatorname{ZIKV}(5,6)$. Considering the above cases and the World Health Organization (WHO) report in May 19, 2016 indicating that 10 countries have shown evidences of transmission of the disease via person to person, possibly through sexual intercourse, it is necessary to bring more attention to this virus (7). Furthermore, Musso et al. in their study have stated that ZIKV can spread via sexual intercourse, ie, male to female sexual transmission. In another study, it was found that infectious viruses were detected in the semen of infected males $(8,9)$. More than $80 \%$ of the infected individuals are probably asymptomatic (10). The stated data indicates that ZIKV infection is a global health concern. Because mothers infected by this virus may give birth to newborns with microcephaly and considering the existence of ZIKV in human fetal brain tissue, it is highly important to consider ways to combat and prevent the disease by avoiding risky sexual behavior, especially in endemic regions. Therefore, more studies should be conducted on this subject to obtain more information and explore solutions in the diagnosis and treatment of this virus.

\section{References}

1. Falcao MB, Cimerman S, Luz KG, Chebabo A, Brigido HA, Lobo IM, et al. Management of infection by the Zika virus. Ann Clin Microbiol Antimicrob. 2016;15(1):57. doi: 10.1186/s12941-016-0172-y. [PubMed: 27686610].

2. Klase ZA, Khakhina S, Schneider Ade B, Callahan MV, GlasspoolMalone J, Malone R. Zika Fetal Neuropathogenesis: Etiology of a Viral Syndrome. PLoS Negl Trop Dis. 2016;10(8):e0004877. doi: 10.1371/journal.pntd.0004877. [PubMed: 27560129].

3. Plourde AR, Bloch EM. A Literature Review of Zika Virus. Emerg Infect Dis. 2016;22(7):1185-92. doi: 10.3201/eid2207.151990. [PubMed: 27070380].

4. Saiz JC, Blazquez AB, De Oya NJ, Merino-Ramos T, Martin-Acebes MA, Escribano-Romero E, et al. Response: Commentary: Zika Virus: the Latest Newcomer. Front Microbiol. 2016;7:1398. doi: 10.3389/fmicb.2016.01398. [PubMed: 27656170].

5. Miner JJ, Cao B, Govero J, Smith AM, Fernandez E, Cabrera OH, et al. Zika Virus Infection during Pregnancy in Mice Causes Placental Damage and Fetal Demise. Cell. 2016;165(5):1081-91. doi: 10.1016/j.cell.2016.05.008. [PubMed: 27180225].

6. Mlakar J, Korva M, Tul N, Popovic M, Poljsak-Prijatelj M, Mraz J, et al. Zika Virus Associated with Microcephaly. $N$ Engl J Med. 2016;374(10):951-8. doi:10.1056/NEJMoa1600651. [PubMed: 26862926].

7. World Health Organization . Zika situation report 2016. Available from: http://who.int/emergencies/zika-virus/situation-report/ 19-may-2016/en/.

8. Foy BD, Kobylinski KC, Chilson Foy JL, Blitvich BJ, Travassos da Rosa $A$, Haddow AD, et al. Probable non-vector-borne transmission of Zika virus, Colorado, USA. Emerg Infect Dis. 2011;17(5):880-2. doi: 10.3201/eid1705.101939. [PubMed: 21529401].

9. Musso D, Roche C, Robin E, Nhan T, Teissier A, Cao-Lormeau VM. Potential sexual transmission of Zika virus. Emerg Infect Dis. 2015;21(2):35961. doi: 10.3201/eid2102.141363. [PubMed: 25625872].

10. Duffy MR, Chen TH, Hancock WT, Powers AM, Kool JL, Lanciotti RS, et al. Zika virus outbreak on Yap Island, Federated States of Micronesia. N Engl J Med. 2009;360(24):2536-43. doi: 10.1056/NEJMoa0805715. [PubMed: 19516034]. 